\title{
MENINGKATKAN KOMPETENSI GURU SEBAGAI PENDIDIK PROFESIONAL DALAM MENGEMBANGKAN PEMBELAJARAN
}

\author{
Isep Djuanda \\ STAI Al-Hamidiyah Jakarta \\ Email : isep_dj@yahoo.com
}

\begin{abstract}
One of the many factors that determines the success of the learning process is teachers' competences since they are the key in improving learning process quality. However, what happens in the real life is far from what it should be. Our education still encounters with the low-competence teachers in implementing the learning process which leads to the low quality of education output.

Teachers are professional educators who need special skills and self-maturity in carrying out their professions. Thus, teachers are obliged to possess various competences, one of which is professional competence. Others are pedagogical, personality and social competences.

Professional competence, as described in Government Regulation No. 74 Year 2008 about Teachers Article 3 paragraph 7, is teachers' competence in mastering the knowledge, science, technology, and/or art and culture of the subject they carry out involving at least the mastery of in-depth and broad learning material; with the relevant concept and method of science, tehcnology and art.

The teachers' ability in mastering subject materials and learning resources, developing learning strategy, model and method, as well as managing classroom can improve learning quality. Those abilities can be gained through teachers-to-be education (pre-position process) as well as education within position.
\end{abstract}

Keywords: Teacher competence, professional teachers, learning process. 


\section{A. PENDAhULUAN}

Guru merupakan faktor utama dalam meningkatan kualitas pembelajaran. Oleh karena itu setiap usaha peningkatan mutu pembelajaran melalui perubahan kurikulum dan silabus, pengembangan strategi, model dan metode, serta penyediaan alat/sumber belajar, hanya akan berarti apabila melibatkan guru yang memiliki kompetensi profesional.

Tersedianya guru yang memiliki kompetensi profesional merupakan kebutuhan untuk mendorong terwujudmya mutu pendidikan, sebagaimana yang dijelaskan dalam Undang-undang No. 13 Tahun 2003 tentang Sistem Pendidikan Nasional, yang dimaksud pendidikan adalah "usaha sadar dan terencana untuk mewujudkan suasana belajar dan proses pembelajaran agar peserta didik secara aktif mengembangkan potensi dirinya untuk memiliki kekuatan spritual keagamaan, pengendalian diri, kepribadian, kecerdasan, akhlaq mulia, serta ketrampilan yang diperlukan dirinya, masyarakat, bangsa dan negara."

Kedudukan guru sebagai tenaga profesional berfungsi untuk meningkatkan martabat guru serta perannya sebagai agen pembelajaran. Sejalan dengan fungsi tersebut, kedudukan guru sebagai tenaga profesional bertujuan untuk melaksanakan sistem pendidikan nasional dan mewujudkan tujuan pendidikan nasional, yakni berkembangnya potensi peserta didik agar menjadi manusia yang beriman dan bertakwa kepada Tuhan Yang Maha Esa, berakhlak mulia, sehat, berilmu, cakap, kreatif, mandiri, serta menjadi warga negara yang demokratis dan bertanggung jawab.

Pengakuan Pemerintah terhadap guru profesional ditandai dengan pemberian sertifikasi profesi dan tunjangan profesi. Sementara guru-guru yang belum men-dapatkan sertifikat pendidik, dipandang belum profesional. Padahal seorang guru, baik yang sudah tersertifikasi atau belum tersertifikasi, tetap menjalankan profesinya sebagai pekerja profesional.

Undang-Undang Guru dan Dosen, telah mendudukan guru sebagai profesi dengan segala hak dan kewajiban yang melekat dengan profesinya. Tapi, pada kenyataannya dunia pendidikan saat ini masih dihadapkan pada masalah rendahnya profesionalitas guru dalam melakukan proses pembelajaran. Diantara faktor yang menyebabkan rendahnya profesionalitas guru adalah antara lain: (1) masih banyak guru yang tidak menekuni profesinya secara utuh. Hal ini disebabkan masih banyak-nya guru yang bekerja diluar jam kerjanya atau mengajar 
di beberapa sekolah guna memenuhi kebutuhan hidup sehari-hari sehingga waktu untuk membaca, menulis, dan menyiapkan materi pembelajaran serta meningkatkan diri tidak ada/tidak bisa dilakukan; (2) program-program pengembangan profesionalitas guru yang dilakukan untuk mencapai standar guru profesional masih jauh dari harapan; (3) belum merata kualitas Perguruan Tinggi (LPTK) dalam menyiapkan calon-calon guru yang profesional sehingga terkesan asal memproduksi lulusan, tanpa memperhitungkan outputnya kelak di lapangan, sehingga menyebabkan masih ada guru yang tidak memahami dan patuh terhadap etika profesi keguruan, (4) kurangnya motivasi guru dalam meningkatkan kualitas diri.

Mengingat peranan strategis guru dalam setiap upaya peningkatan mutu pendidikan, maka peningkatan kompetensi profesional guru merupakan kebutuhan yang sangat penting dalam mendorong terwujudmya mutu pendidikan, sebagaimana yang diamanatkan dalam pembangunan nasional. Meskipun dalam perspektif manajemen pendidikan bahwa mutu pendidikan bukan hanya ditentukan oleh guru, melainkan oleh mutu masukan (peserta didik ), sarana dan prasarana, manajemen, dan faktorfaktor eksternal lainnya, akan tetapi seberapa banyak siswa mengalami kemajuan belajar, banyak bergantung pada kemampuan guru dalam mengembangkan pembelajaran.

Sebagai komponen yang bertugas mengembangkan pembelajaran, guru akan melaksanakan berbagai kegiatan agar tercapai tujuan pembelajaran yang telah direncanakan. Untuk mencapai tujuan tersebut E.Mulyasa mengatakan bahwa guru harus memainkan fungsinya sebagai pendidik, pengajar, pembimbing, pelatih, pengikat, pembaharu, model, teladan, peneliti, pendorong kreativitas, pembangkit pandangan, pekerja rutin, pembaca cerita, aktor, emansipator, evaluator dan kulminator. ${ }^{1}$

Perkembangan zaman yang pesat membawa perubahan berfikir manusia, termasuk didalamnya perubahan paradigma dalam peningkatan mutu pendidikan (pembelajaran). Paradigma penting dalam upaya peningkatan mutu pendidikan itu adalah : (1) kegiatan pembelajaran akan bergeser dari "Schooling " ke "learning", dari " teaching " ke "learning",(2) dari " student"

\footnotetext{
${ }^{1}$ E. Mulyasa.2005.Menjadi Guru Profesional .Bandung: Remaja Rosda Karya. h.35.
} 
ke "learner",(3) proses " learning " bisa terjadi di sekolah, rumah maupun di kantor untuk membentuk "the learning society". ${ }^{2}$ Menurut Hardiyanto ada empat pilar pendidikan yang direkomendasikan oleh UNESCO mengenai paradigma baru itu yaitu: (1) belajar mengetahui ( learning to know), (2) belajar melakukan ( learning to do ), (3) belajar hidup dalam kebersamaan ( learning to live together ), dan (4) belajar menjadi diri sendiri (learning to be). ${ }^{3}$

\section{B. PENGERTIAN GURU SEBAGAI PROFESI DAN PROFESIONAL.}

\section{Profesi.}

Menurut HAR Tilaar, profesi merupakan jabatan di dalam suatu hierarki birokrasi, yang menuntut keahlian tertentu serta memiliki etika khusus untuk jabatan tersebut serta pelayanan baku terhadap masyarakat ${ }^{4}$. Menurut Wirawan profesi adalah pekerjaan yang untuk melaksanakannya memerlukan sejumlah persyaratan tertentu ${ }^{5}$. Hal senada juga diungkapkan oleh A. Suhaenah Suparno bahwa ciri-ciri dari suatu profesi diantaranya, sebagai berikut:

a. Suatu pekerjaan menjadi suatu profesi apabila di dalam kegiatan-kegiatannya menerapkan hasil temuan dari ilmu dan teknologi. Prinsip-prinsip yang ditemukan dalam berbagai eksperimen misalnya, dapat dijadikan acuan untuk melaksanakan profesi tersebut.

b. Suatu profesi mempunyai akses terhadap praktek, karena suatu profesi tidak mungkin hanya mengandalkan renungan-renungan atau teori-teori tanpa melalui akses terhadap praktek layanan masyarakat merupakan pengakuan dari jasa profesi tersebut.

c. Suatu profesi memerlukan pendidikan dan latihan khusus yang relatif cukup lama sehingga orang-orang yang dipersiapkan menyandang suatu profesi tersebut telah

\footnotetext{
${ }^{2}$ Laporan Komisi Nasional Pendidikan., 2001. Menuju Pendidikan Dasar Bermutu dan Merata (Jakarta:Depdiknas. h.2)

${ }^{3}$ Hardiyanto.2004. Mencari Sosok Desentralisasi Manajemen Pendidikan . Jakarta:Rineka Cipta. h.10.

${ }^{4}$ HAR Tilaar.2002. Membenahi Pendidikan Nasional . Jakarta: Rineka Cipta. h.86.

${ }^{5}$ Wirawan.2002. Profesi dan Standar Evaluasi . Jakarta: Yayasan Bangun Indonesia \& Uhamka.h.9.
} 
melalui suatu proses yang intensif dan praktek berulangulang.

d. Suatu profesi juga bercirikan adanya pertambahan didalam jabatan. Seorang penyandang profesi tidak akan berada di dalam "status quo" dimana dari tahun ke tahun, dari dekade kedekade dia berada didalam status yang sama. Pertumbuhan tersebut juga harus ditafsirkan sebagai pengembangan dan peningkatan dalam fungsi pendalaman, kecanggihan, dan adaptasi terhadap perubahan-perubahan. Seorang yang menyandang suatu profesi seyogianya menjalankan tugas.

e. Para penyandang profesi biasanya membentuk asosiasi atau perkumpulan. Tujuan pembentukan asosiasi atau perkumpulan ini adalah untuk dapat mengadakan komunikasi yang khusus dalam mengembangkan profesi tersebut. Semua pem-baharuan, tantangan-tantangan, dan tema-tema dibicarakan untuk memberikan tentang masalah kesejahteraan.

f. Pengakuan terhadap suatu profesi diberikan oleh masyarakat pengguna jasa profesi tersebut. Tidak dengan sendirinya suatu pekerjaan yang diproklamasikan sebagai suatu profesi memperoleh pengakuan dari masyarakat.

g. Meskipun suatu profesi merupakan suatu pekerjaan, dimana seseorang menerima imbalan namun citra melayani menjadi ciri suatu profesi.

h. Suatu profesi terikat pada kode etik, yaitu perangkat aturan, yang mengatur keputusan-keputusan bertindak terhadap apa pelanggaran yang dilakukan dalam berakibat baik sosial maupun psikologis.

i. Suatu profesi memberikan tanggungjawab (responsibility) dan tugas tanggungan jawab yang jelas (accountability) ${ }^{6}$.

Kriteria guru menurut National Education Association (NEA) sebagaimana dikutip oleh Soetjipto, adalah sebagai berikut:

(a) jabatan yang melibatkan intelektual; (b) jabatan yang melibatkan suatu bidang yang khusus; (c) jabatan yang

\footnotetext{
${ }^{6}$ A.Suhaenah Suparno.1998”Strategi ke Arah Profesionalisasi Tenaga Kependidikan”, Makalah disampaikan pada Diskusi Prospek Pendidikan Masa Depan, Depdikbud, Jakarta, 15-16 Desember 1998,h.4-5.
} 
memerlukan persiapan profesi yang lama; (d) jabatan yang memerlukan latihan dan berkesinambungan; (e) jabatan yang menjanjikan karier hidup dan keanggotaan yang permanen; (f) jabatan yang menentukan baku (standarnya) sendiri; (g) jabatan yang mementingkan layanan di atas kepentingan pribadi, dan (h) jabatan yang mempunyai organisasi profesional yang kuat dan terjalin erat ${ }^{7}$.

Menurut Vollmer dan Mills yang dikutip oleh Peter Jarvis menyatakan bahwa profesi adalah suatu pekerjaan yang didasarkan atas studi intelektual dan latihan yang khusus, tujuannya untuk menyediakan pelayanan ketrampilan atau advis terhadap yang lain dengan bayaran atau upah tertentu. (a profession may perhaps be definedes as occupation based upon specialized intellectual study and training, the purpose of which is to supply skilled service or advice to others for a defitive fee a salary $)^{8}$.

Sementara itu, menurut Ornstein dan Levine yang dikutip oleh Soetjipto dan Raflis Kosasi, menyatakan bahwa profesi adalah jabatan yang sesuai dengan pengertian profesi di bawah ini:

a. Melayani masyarakat, merupakan karier yang akan dilaksanakan sepanjang hayat (tidak berganti-ganti pelayanan).

b. Memerlukan bidang ilmu dan ketrampilan tertentu diluar jangkauan khalayak ramai (tidak setiap orang dapat melakukannya).

c. Menggunakan hasil penelitian dan aplikasinya dari teori ke praktek (teori baru dikembangkan dari hasil penelitian).

d. Memerlukan pelatihan khusus dengan waktu yang panjang.

e. Terkendali lisensi baku dan atau mempunyai persyaratan masuk (untuk menduduki jabatan tersebut memerlukan izin tertentu atau ada persyaratan khusus yang ditentukan untuk dapat mendudukinya).

f. Otonomi dalam membuat keputusan tentang ruang lingkup kerja tertentu (tidak diatur oleh orang luar).

g. Menerima tanggung jawab terhadap keputusan yang diambil dan unjuk kerja yang ditampilkan yang berhubungan dengan layanan yang diberikan.

\footnotetext{
${ }^{7}$ Soetjipto dan Kosasi, 2004. Profesi Keguruan. Jakarta: Rineka Cipta.,h.18.

${ }^{8}$ Peter Jarvis.1983. Standars and Competencies .London: Kogan Page,h.21.
} 
h. Mempunyai komitmen terhadap jabatan dan klien dengan penekanan terhadap layanan yang akan diberikan.

i. Menggunanakan administrator untuk mendahulukan profesinya; relatif bebas dalam supervisi dalam jabatan.

j. Mempunyai organisasi yang diatur oleh anggota profesi sendiri.

k. Mempunyai asosiasi profesi dan atau kelompok "elit" untuk mengetahui dan mengakui keberhasilan anggotanya.

1. Mempunyai kode etik untuk menjelaskan hal-hal yang meragukan atau menyangsikan yang berhubungan dengan layanan yang diberikan.

m. Mempunyai kadar kepercayaan yang tinggi dari publik dan kepercayaan dari setiap anggotanya.

n. Mempunyai status sosial dan ekonomi yang tinggi ${ }^{9}$.

Berdasarkan pendapat di atas, dapat dipahami bahwa profesi guru merupakan profesi yang memerlukan keahlian khusus yang diperoleh melalui proses pendidikan dan pelatihan.

\section{Profesional.}

Istilah "profesional" merupakan kata benda dari profesi sebagai lawan dari amatir, yang berkaitan seseorang yang menerima bayaran atau jasa dari tugas atau jasa pekerjaannya. Menurut Philip Suprastowo: pekerjaan profesional ada dua, yaitu: hard profession dan soft profession. Pekerjaan yang dapat dikategorikan sebagai hard profession adalah apabila pekerjaan tersebut dapat didetailkan (dirinci) dalam perilaku dan langkahlangkah yang jelas dan pasti. Pendidikan yang diperlukan bagi profesi ini adalah menghasilkan out put pendidikan yang distandarisasikan. Kualifikasi lulusan jelas dan seragam dimanapun pendidikan berlangsung. Pendidikan dokter dan pilot merupakan contoh kategori hard profession. Sedangkan pekerjaan yang dikategorikan sebagai soft profession adalah diperlukan kadar seni dalam melaksanakan pekerjaan tersebut yang tidak dapat dijabarkan secara rinci dan pasti. Implikasi kategori soft profession tidak menuntut pendidikan yang menghasilkan lulusan yang memiliki bekal kemampuan minimal. Kemampuan itu dari waktu ke waktu harus ditingkatkan agar

\footnotetext{
${ }^{9}$ Soetjipto dan Kosasi, 2004. Profesi Keguruan ( Jakarta: Rineka Cipta ),h.1516.
} 
melaksanakan tugas pekerjaannya sesuai dengan perkembangan masyarakat ${ }^{10}$.

Menurut A. Suhaenah Suparno: istilah profesional merupakan pengertian sifat suatu pekerjaan yang dilakukan dengan sungguh-sungguh dengan menunjukkan ciri-ciri suatu profesi. Seseorang yang profesional, menunjukkan rasa tanggungjawab dan siap untuk dituntut apabila ukuran-ukuran keberhasilannya tidak dipenuhi. Tuntutan ini dapat mengambil bentuk bermacam-macam, mulai dari yang didukung oleh aturan-aturan legal sampai kepada hukuman-hukuman yang bersifat psikologis, berupa pernyataan ketidakpuasan sampai kepada sifat-sifat pelecehan dari pihak pemakai jasa profesi tersebut ${ }^{11}$.

Undang Nomor 14 Tahun 2005 tentang Guru dan Dosen pada pasal 1 ayat 4 mendefinisikan bahwa profesional adalah pekerjaan atau kegiatan yang dilakukan oleh seseorang dan menjadi sumber penghasilan kehidupan yang memerlukan keahlian, kemahiran, atau kecakapan yang memenuhi standar mutu atau norma tertentu serta memerlukan pendidikan profesi.

Menurut Arifin guru yang profesional dipersyaratkan mempunyai: ${ }^{12}$

a. Dasar ilmu yang kuat sebagai pengejawantahan terhadap masyarakat teknologi dan masyarakat ilmu pengetahuan.

b. Penguasaan kiat-kiat profesi berdasarkan riset dan praksis pendidikan yaitu ilmu pendidikan sebagai ilmu praksis bukan hanya merupakan konsep-konsep belaka. Pendidikan merupakan proses yang terjadi di lapangan dan bersifat ilmiah, serta riset pendidikan hendaknya diarahkan pada praksis pendidikan masyarakat Indonesia.

c. Pengembangan kemampuan profesional berkesinambungan. Profesi guru merupa-kan profesi yang berkembang terus menerus dan berkesinambungan antara LPTK dengan praktek pendidikan.

${ }^{10}$ Philip Suprastowo, 2001. Guru Pada Era Reformasi Kajian Dalam Meningkatkan Profesional Guru. Jakarta: Balitbang Depdiknas, h.32.

${ }^{11}$ A. Suhaenah Suparno, op.cit., h.5.

${ }^{12}$ Arifin, I. 2000. Profesionalisme Guru: Analisis Wacana Reformasi Pendidikan dalam Era Globalisasi. Simposium Nasional Pendidikan di Universitas Muhammadiyah Malang, h.1. 
Dari uraian di atas, dapat disimpulkan bahwa guru merupakan jabatan profesional, yang dalam menjalankan tugas dan fungsinya diperlukan keahlian yang diperoleh melalui proses pendidikan dan pelatihan, berhimpun dalam organisasi profesi guru, memiliki/menjalankan kode etik guru.

\section{KOMPETENSI PROFESIONAL GURU}

Kata kompetensi berasal dari bahasa Inggris, yaitu competence yang artinya kecakapan atau kemampuan. Kompetensi juga dapat diartikan sebagai ciri mendasar yang terdapat pada diri seseorang yang memiliki hubungan sebab akibat dengan kinerjanya yang efektif atau unggul dalam suatu pekerjaan. ${ }^{13}$

Undang-undang No. 14 Tahun 2005 Pasal 1, menjelaskan bahwa kompetensi adalah seperangkat pengetahuan, keterampilan, dan perilaku yang harus dimiliki, dihayati, dan dikuasai oleh guru atau dosen dalam melaksanakan tugas keprofesionalannya.

Dalam melakukan kewenangan profesionalnya, guru dituntut memiliki seperangkat kemampuan (kompetensi) kependidikan. Dalam hal ini Charles E. Johnson mengemukakan beberapa kompetensi yang harus dimiliki oleh guru, yaitu: komponen kinerja (performance component), komponen bahan pengajaran (the teaching subject component), komponen penyesuaian pribadi (the personal adjusment component), komponen sikap (the attitudes component) ${ }^{I 4}$.

Berbagai pandangan di atas menunjukan bahwa kompetensi guru adalah kemampuan dan keahlian khusus dalam bidang keguruan sehingga ia mampu melakukan tugas dan fungsinya sebagai guru profesional.

Salah satu kompetensi yang perlu dimiliki guru dalam menjalankan tugas profesinya adalah kompetensi profesional, disamping kompetensi pedagogik, kompetensi kepribadian dan kompetensi sosial.

Kompetensi profesional sebagaimana dijelaskan dalam Peraturan Pemerintah No.74 Tahun 2008 tentang Guru Pasal 3 ayat 7 , merupakan kemampuan Guru dalam menguasai

\footnotetext{
13 Supardi.Darwyansyah.et.al. 2009.Profesi Keguruan. Jakarta: Diadit Media.,h.39

${ }^{14}$ Charles E.Johnson,. 1974. Motivation and Leadership at Work. New York: Mc. Graw Hill Companies Inc.
} 
pengetahuan bidang ilmu pengetahuan, teknologi, dan/atau seni dan budaya yang diampunya yang sekurang-kurangnya meliputi penguasaan: 1) materi pelajaran secara luas dan mendalam sesuai dengan standar isi program satuan pendidikan, mata pelajaran, dan/atau kelompok mata pelajaran yang akan diampu; dan 2) konsep dan metode disiplin keilmuan, teknologi, atau seni yang relevan, yang secara konseptual menaungi atau koheren dengan program satuan pendidikan, mata pelajaran, dan/atau kelompok mata pelajaran yang akan diampu.

Standar nasional pendidikan, penjelasan Pasal 28 ayat (3) butir c dikemukakan bahwa yang dimaksud kompetensi profesional adalah kemampuan penguasaan materi pembelajaran secara luas dan mendalam yang memungkinkan membimbing pesrta didik memenuhi standar kompetensi yang ditetapkan dalam standar nasional pendidikan, yang terinci dalam rumusan sebagai berikut: 1) menguasai secara luas dan mendalam substansi dan metodologi dasar keilmuan, 2) menguasai materi ajar dalam kurikulum, 3) mampu mengembangkan kurikulum dan pembelajaran secara kreatif dan inovatif, 4) menguasai dasardasar materi kegiatan ekstra kurikuler yang mendukung tercapainya tujuan utuh pendidikan siswa, 4) mampu menilai dan memperbaiki pembelajaran melalui penelitian tindakan kelas (PTK)

Menurut Sardiman terdapat sepuluh kompetensi yang harus dimiliki oleh seorang guru profesional, yaitu:

1. Menguasai bahan ajar.

2. Mengelola belajar mengajar.

3. Mengelola kelas.

4. Menggunakan media/sumber belajar.

5. Menguasai landasan-landasan pendidikan.

6. Mengelola interaksi belajar mengajar.

7. Menilai prestasi siswa untuk kepentingan pengajaran.

8. Mengenal fungsi dan program bimbingan dan penyuluhan di sekolah.

9. Mengenal dan menyelenggarakan administrasi sekolah.

10. Memahami prinsip-prinsip dan menafsirkan hasil penelitian pendidikan guna keperluan pengajaran. ${ }^{15}$

\footnotetext{
${ }^{15}$ Sardiman A.M. 1992. Interaksi dan Motivasi Belajar Mengajar. Jakarta: Rajawali Press. h.123.
} 
Kesepuluh kompetensi professional yang perlu dimiliki dan dikuasai guru dapat dijelaskan sebagai berikut:

1. Guru dituntut menguasai bahan ajar.

Guru yang profesional adalah guru yang siap dengan sejumlah sumber belajar dan materi ajar guna membantu peserta didik mampu menguasai pengetahuan, ketrampilan, dan sikap. Guru hendaknya menguasai materi pembel-ajaran yang sesuai dengan bidang keahliannya.

A. Samana menjelaskan indikator guru yang memiliki kompetensi profesional dalam hal penguasaan bahan pengajaran adalah sebagai berikut:

a. Menguasai bahan bidang studi dalam kurikulum sekolah, seperti:

1) mengkaji bahan kurikulum bidang studi

2) mengkaji isi buku teks bidang studi yang bersangkutan

3) melaksanakan kegiatan-kegiatan yang disarankan dalam kurikulum

bidang studi yang bersangkutan

b. Menguasai bahan pendalaman atau aplikasi bidang studi, melalui:

1) mempelajari ilmu yang relevan

2) mempelajari aplikasi bidang ilmu kedalam bidang ilmu lain

3) mempelajari cara menilai kurikulum bidang studi ${ }^{16}$.

2. Guru mampu mengelola program belajar mengajar

Kemampuan guru dalam mengelola pembelajaran ditandai dengan ke-mampuan guru dalam merencanakan, mengorganisir, melaksanakan dan meng-evaluasi pembelajaran. Guru mampu mengembangkan proses belajar yang aktif, inovatif, kreatif, efektif dan menyenangkan. Guru mampu mengembangkan pem-belajaran yang berpusat pada siswa, dimana partisipasi dan kreatifitas peserta didik nampak dalam proses belajar.

3. Guru mampu mengelola kelas

Pengelolaan kelas merupakan ketrampilan guru untuk menciptakan iklim pembelajaran yang kondusif, dan mengendalikannya jika terjadi gangguan dalam pembelajaran. E. Mulyasa menjelaskan ketrampilan mengelola kelas memiliki komponen sebagai berikut:

${ }^{16}$ A.Samana. 1994. Profesionalisme Keguruan. Yogyakarta: Kanisius. h.123. 
a. Penciptaan dan pemeliharaan iklim pembelajaran yang optimal:

1) menunjukkan sikap tanggap dengan cara memandang secara seksama men-dekati, memberikan pernyataan, dan memberi reaksi terhadap terhadap gangguan kelas

2) membagi perhatian secara visual dan verbal

3) memusatkan perhatian secara visual dan verbal

4) memberi petunjuk yang jelas

5) memberi teguran secara bijaksana

6) memberi penguatan ketika diperlukan

b. Ketrampilan yang berhubungan dengan pengendalian kondisi belajar yang optimal:

1) modifikasi perilaku:

- mengajarkan perilaku baru dengan contoh dan pembiasaan

- meningkatkan perilaku yang baik melalui penguatan

- mengurangi perilaku buruk dengan hukuman

2) pengelolaan kelompok dengan cara:

- peningkatan kerjasama dan ketertiban

- menangani konflik dan memperkecil masalah yang timbul

3) menemukan dan mengatasi perilaku yang menimbulkan masalah:

- pengabaian yang direncanakan

- campur tangan dengan isyarat

- menguasai secara ketat

- mengakui perasaan negatif peserta didik

- mendorong peserta didik untuk mengungkapkan perasaan

- menyusun kembali program belajar

- menghilangkan ketegangan dengan humor, dan

- mengekang secara fisik ${ }^{17}$

4. Guru mampu menggunakan media dan sumber belajar.

Media pengajaran adalah alat yang digunakan guru dalam menyampaikan informasi/konsep/pesan kepada peserta didik baik secara langsung maupun tidak langsung. Sedangkan sumber belajar adalah rujukan atau

\footnotetext{
${ }^{17}$ E. Mulyasa. 2005. Menjadi Guru Profesional. Bandung: Remaja Rosdakarya, h.91.
} 
referensi yang digunakan guru dalam menyampaikan informasi/konsep/pesan kepada peserta didik.

Sebagai mediator, guru hendaknya memiliki pengetahuan dan pemahaman yang cukup tentang media dan sumber belajar, yang merupakan alat komunikasi untuk lebih mengefektifkan proses belajar mengajar. Dengan demikian media dan sumber belajar merupakan kebutuhan dasar dalam pembelajaran yang bersifat melengkapi dan merupakan bagian integral untuk berhasilnya proses pembelajaran di sekolah.

Guru tidak cukup hanya memiliki pengetahuan tentang media dan sumber belajar, tetapi juga memiliki ketrampilan dalam memilih dan menggunakannya. Untuk itu guru perlu melakukan latihan dan praktik secara berkesinambungan dan sistematis, baik melalui pre-service training maupun melalui in-service training. Memilih dan menggunakan media pendidikan harus sesuai dengan tujuan pembelajaran, materi pembelajaran, metode pembelajaran, evaluasi pembelajaran, dan kemampuan guru serta minat dan kemampuan siswa.

5. Guru menguasai landasan-landasan kependidikan

Ada beberapa landasan kependidikan yang perlu dipahami oleh guru, di-antaranya landasan filosofis, landasan yuridis, landasan ilmu pengetahuan dan landasan agama, yang dikaitkan dengan: 1) pemahaman peserta didik, (2) pemahaman profesi guru, (3) pemahaman prinsip-prinsip berinteraksi dengan peserta didik, (4) pemahaman hubungan antara sekolah dan masyarakat, dan (5) pemahaman tentang tugas-tugas dan fungsi sebagai guru.

6. Guru mampu mengelola interaksi belajar mengajar

Proses belajar mengajar merupakan inti dari tugas pokok dan fungsi profesi guru. Ada tiga kompetensi dasar guru dalam melaksanakan proses belajar mengajar, yaitu; 1) kemampuan dalam menyampaikan dan menjelaskan materi pelajaran secara sistematis, 2) kemampuan dalam mengatur komunikasi antara guru dengan siswa, dan antar siswa dengan siswa, 3) kemampuan membimbing diskusi dalam kelas, 4) dan kemampuan mengelola kelas.

7. Guru mampu melaksanakan evaluasi pembelajaran

Evaluasi pembelajaran merupakan instrumen yang dapat memberikan informasi dan umpan balik kepada siswa, guru, 
orangtua dan sekolah tentang ketercapaian proses belajar yang telah dilaksanakan.

Ada tiga kompetensi dasar guru dalam pelaksanaan evaluasi pembelajaran, yaitu: 1) kemampuan dalam membuat kisi-kisi soal, 2) kemampuan membuat pem-bobotan terhadap item-item soal, baik dari segi (kognitif, afektif, dan psikomotorik), maupun dari tingkat kesukaran (mudah, sedang, sulit), dan 3) menjabar-kan konstruksi tes dalam bentuk item-item soal secara jelas dan operasional terukur.

8. Guru melaksanakan layanan bimbingan dan konseling.

Tehnik utama yang dilaksanakan dalam layanan bimbingan dan koseling ini adalah memfokuskan pada pendekatan "psychoeducator" sehingga dalam implementasinya harus dilaksanakan oleh Guru Bimbingan dan Konseling (BK). Ada beberapa kompetensi dasar yang harus dijalankan oleh guru BK di sekolah, yaitu: 1) membuat program bimbingan dan penyuluhan, 2) melaksanakan program layanan informasi, 3) melaksanakan bimbingan akademis, 4) membuat daftar nilai, dan 5) membuat buku catatan pribadi peserta didik.

9. Guru mampu menyelenggarakan administrasi pendidikan.

Tugas utama guru adalah mengelola proses belajar mengajar dalam suatu lingkungan tertentu, yaitu sekolah. Guru perlu memahami apa yang terjadi di lingkungan kerjanya. Di sekolah, guru berada dalam lingkungan administrasi sekolah. Sekolah melaksanakan kegiatannya untuk menghasilkan lulusan yang jumlah serta mutunya telah ditetapkan. Dalam lingkup administrasi sekolah peranan guru sangat penting.

Dengan demikian sebagai pendidik, guru perlu memiliki pemahaman/-wawasan tentang administrasi pendidikan, baik yang menyangkut administrasi guru maupun admistrasi kelas. Yang termasuk administrasi guru adalah program tahunan, program semester, silabus, rencana program pembelajaran, refleksi RPP dan lain-lain. Wawasan itu dapat membantu mengambil keputusan yang tepat dalam melaksanakan tugasnya.

Dalam menetapkan kebijakan, perencanaan, pengorganisasian, pengarahan, pengawasan, pembiayaan dan penilaian kegiatan kurikulum, dan lain-lain, perlu melibatkan guru terkait pengelolaan administrasi sekolah. Karena, administrasi sekolah adalah pekerjaan yang sifatnya kolaboratif, 
artinya pekerjaan yang didasarkan atas kerjasama, dan bukan bersifat individual.

Peran guru profesional dalam keseluruhan program pendidikan di sekolah diwujudkan untuk mencapai tujuan pendidikan yang berupa perkembangan peserta didik secara optimal. Untuk maksud tersebut maka peran guru profesional itu mencakup tiga bidang layanan, yaitu: layanan instruksional, layanan administrasi, dan layanan bantuan akademik sosial pribadi. $^{18}$

10. Guru mampu melaksanakan penelitian tindakan kelas

Penelitian tindakan kelas merupakan suatu cara memperbaiki dan meningkatkan kemampuan guru dalam melaksanakan pembelajaran baik di kelas maupun di luar kelas. Tujuan utama dari penelitian tindakan kelas adalah untuk: 1) memperbaiki dan meningkatkan kondisi serta kualitas pembelajaran di kelas, 2) meningkatkan layanan profesional dalam konteks pembelajaran di kelas, khususnya layanan pada peserta didik, 3) memberikan kesempatan kepada guru untuk melakukan tindakan dalam pembelajaran yang direncanakan di kelas, dan 4) memberikan kesempatan kepada guru untuk melakukan pengkajian terhadap kegiatan-kegiatan pembelajaran yang dilakukan.

Ada beberapa kompetensi dasar yang perlu dimiliki oleh guru dalam melaksanakan penelitian tindakan kelas, yaitu: 1) mampu membuat desain penelitian, (2) mampu mengolah data dan menginterpretasikannya secara tepat, dan (3) membuat hasil penelitian atas dasar temuan penelitian tindakan kelas yang telah dilaksanakannya ${ }^{19}$.

\section{PENINGKATAN PROFESI GURU MELALUI PENDIDIKAN DAN LATIHAN}

Peningkatan profesi guru adalah upaya dalam meningkatkan kapasitas guru dalam menjalankan tugas profesinya. Menurut Eddy Soewarni, pengembangan profesi guru dilingkungan pendidikan dasar dan menengah diarahkan pada kualitas profesionalisme, penilaian kinerja secara obyektif, transparan dan akuntabilitas, serta memotivasi untuk

\footnotetext{
${ }^{18}$ Soetjipto dan Raflis Kosasi. 1999. Profesi Keguruan., Jakarta: Rineka Cipta. h.2.

${ }^{19}$ Ibid., h.107.
} 
meningkatkan kinerja dan prestasi. Peningkatan profesi guru pada dasarnya meliputi peningkatan kualifikasi pendidikan ke jenjang S1, S2, S3, dan sertifikasi mengajar bagi lulusan non LPTK, pengembangan kompetensi yang meliputi kepribadian, profesional (kognitif, afektif, psikomotorik) dan sosial, serta pengembangan karier $^{20}$.

Menurut Soetjipto bahwa dalam rangka meningkatkan mutu, baik mutu profesional maupun mutu layanan, guru perlu meningkatkan sikap profesinya. Menurutnya, ada dua jalur pengembangan profesi guru, yaitu: 1) pengembangan profesi guru selama pendidikan prajabatan, dan 2) pengembangan profesi guru selama dalam jabatan. ${ }^{21}$

1. Peningkatan profesi guru selama pendidikan pra jabatan.

Dalam pendidikan pra jabatan, calon guru dididik dalam berbagai pengetahuan, sikap, dan ketrampilan yang diperlukan dalam pekerjaannya nanti. Pembentukan sikap yang baik tidak mungkin muncul begitu saja, tetapi harus dibina sejak calon guru memulai pendidikannya di lembaga pendidikan guru.

Guru-guru yang bermutu lahir dari proses pendidikan calon guru yang diselenggarakan oleh lembaga pendidikan guru yang bermutu. Lembaga penyedia calon guru tersebut diharapkan mampu mendesain dan melaksanakan program pendidikannya sehingga dapat mencetak guru yang dapat memenuhi kualifikasi sebagai pendidik dan memiliki kompetensi yang dibutuhkan sebagai pendidik. Perlu mendidik calon guru yang memiliki minat dan potensi sebagai guru, serta berprestasi pada jenjang pendidikan sebelumnya (SMA/MA), sehingga diperoleh input calon guru yang lebih baik.

Menurut Deddy Supriadi, peningkatan mutu pendidikan pra jabatan dilakukan melalui empat jalur, yaitu:

1) Pengendalian mutu pendidikan pra jabatan guru, dimana jumlah LPTK harus dibatasi dan dipihak lain hanya LPTK yang diberi otoritas untuk

\footnotetext{
${ }^{20}$ Eddy Soewarni. 2001. Kebijakan Pedoman Pengembangan Profesi Guru. www. Depdiknas. Go.id. h.1.

${ }^{21}$ Soetjipto dan Raflis Kosasi., op. cit., h.55.
} 
menghasilkan guru atau tenaga kependidikan. LPTK negeri atau LPTK swasta terpilih yang dapat menghasilkan tenaga guru, agar pengendalian guru dapat dilakukan secara ketat.

2) Reorientasi kurikulum pendidikan pra jabatan guru, MKDU dipergunakan dengan cara menggabungkan menjadi satu mata kuliah terpadu dan menggunakan jatah untuk mata kuliah yang membekali pengetahuan dalam materi yang diajarkan dan ketrampilan keguruan.

3) Perbaikan proses belajar mengajar. Untuk selalu berusaha mengadakan eksperimen dan memperkaya perbendaharaan strategi pembelajarannya dengan tehnik-tehnik baru yang pada gilirannya mereka dapat berkesinambungan memperbaiki layanan pembelajaran dan kependidikan para siswanya.

4) Pengakraban calon guru dengan tugas keguruan. Para calon guru sejak dini secara intensif perlu diperkenalkan dengan berbagai cara pengembangan materi ajar, tehnik pembelajaran, pemantauan proses dan penilaian hasil belajar serta bimbingan dan konseling yang menjadi tugas profesionalnya. $^{22}$

\section{Peningkatan profesi guru selama dalam jabatan}

Upaya

mendayagunakan, memajukan

dan meningkatkan produktifitas kerja guru dalam mengembangkan wawasan keilmuan, wawasan berfikir, sikap kerja dan keterampilan dalam pelaksanaan tugasnya diperlukan peningkatan profesi guru melalui pendidikan dan pelatihan dalam jabatan (in-service training).

Pengembangan profesi guru juga dapat dilakukan melalui pemenuhan kualifikasi akademik pendidik, program sertifikasi profesi guru, dan memberdayakan musyawarah guru mata pelajaran, mengefektifkan pusat kegiatan guru dan kelompok kerja guru maupun lesson study, yang memungkinkan para guru untuk berbagi pengalaman dalam memecahkan masalah-masalah yang dihadapi saat melakukan kegiatan belajar mengajar.

${ }^{22}$ Deddy Supriadi dan Fasli Djalal. 2001. Reformasi Pendidikan Dalam Konteks Otonomi Daerah. Jakarta: Adicipta. h.249. 
Peningkatan profesi guru harus dipandang sebagai proses yang terus menerus. Dalam proses ini, pendidikan pra-jabatan, pendidikan dalam jabatan termasuk penataran, pembinaan dari organisasi profesi dan tempat kerja, penghargaan masyarakat terhadap profesi keguruan, penegakan kode etik profesi, sertifikasi, peningkatan kualitas calon guru, imbalan, dan lain-lain secara bersama-sama menentukan pengembangan kompetensi profesional guru.

\section{E. PENUTUP}

1. Guru merupakan jabatan profesional, yang dalam menjalankan tugas dan fungsinya membutuhkan keahlian yang diperoleh melalui proses pendidikan dan pelatihan, berhimpun dalam organisasi profesi guru, memiliki/menjalankan kode etik guru.

2. Setiap usaha peningkatan kualitas pembelajaran melalui perubahan kurikulum dan silabus, pengembangan strategi, model dan metode, serta penyediaan alat/sumber belajar, hanya akan berarti apabila melibatkan guru yang memiliki kompetensi profesional.

3. Kompetensi profesional yang dimiliki guru akan berdampak pada mutu pembelajaran. Guru mampu mengembangkan pembelajaran yang aktif, inovatif, kreatif dan menyenangkan, serta partisipasi dan kreatiitas peserta didik dalam belajar juga meningkat.

4. Pengembangan kompetensi profesional guru dapat dilakukan melalui program pra jabatan dan program dalam jabatan.

\section{DAFTAR PUSTAKA}

Arifin, I. 2000. Profesionalisme Guru: Analisis Wacana Reformasi Pendidikan dalam Era Globalisasi. Simposium Nasional Pendidikan di Universitas Muhammadiyah Malang.

A.Samana. 1994. Profesionalisme Keguruan. Yogyakarta: Kanisius 
| Isep Djuanda

Deddy Supriadi dan Fasli Djalal. 2001. Reformasi Pendidikan Dalam Konteks Otonomi Daerah. Jakarta: Adicipta.

E. Mulyasa. 2005. Menjadi Guru Profesional. Bandung: Remaja Rosda Karya.

Hardiyanto. 2004. Mencari Sosok Desentralisasi Manajemen Pendidikan. Jakarta: Rineka Cipta.

Johnson, Charles E. 1974. Motivation and Leadership at Work. New York: Mc. Graw Hill Companies Inc.

Komisi Nasional Pendidikan. 2001. Мепији Pendidikan Dasar Bermutu dan Merata. Jakarta: Depdiknas.

M. Sardiman A. 1992. Interaksi dan Motivasi Belajar Mengajar. Jakarta: Rajawali Press.

Mulyasa, E. 2005. Menjadi Guru Profesional. Bandung: Remaja Rosda Karya.

Peter Jarvis. 1983. Standars and Competencies .London: Kogan

Soetjipto dan Kosasi. 2004. Profesi Keguruan. Jakarta: Rineka Cipta.

Soewarni, Eddy. 2001. Kebijakan Pedoman Pengembangan Profesi Guru. $\mathrm{http} / / \mathrm{www}$.depdiknas.go.id.

Supardi. Darwyansyah.et.al. 2009.Profesi Keguruan. Jakarta: Diadit Media

Suparno, A. Suhaenah. 1998. Strategi ke Arah Profesionalisasi Tenaga Kependidi-kan. Jakarta: Depdikbud. 
Meningkatkan Kompetensi Guru Sebagai Pendidik Profesional Dalam Mengembangkan Pembelajaran |

Suprastowo, Philip. 2001. Guru Pada Era Reformasi Kajian Dalam Meningkatkan Profesional Guru. Jakarta: Balitbang Depdiknas.

Tilaar, HAR. 2002. Membenahi Pendidikan Nasional. Jakarta: Rineka Cipta.

Wirawan. 2002. Profesi dan Standar Evaluasi. Jakarta: Yayasan Bangun Indonesia \& Uhamka. h.9. 